\title{
ATF4 Gene
}

National Cancer Institute

\section{Source}

National Cancer Institute. ATF4 Gene. NCI Thesaurus. Code C107457.

This gene plays a role in transcription. 